\title{
Protectors on trial? Prosecuting peacekeepers for war crimes and crimes against humanity in the International Criminal \\ Court
}

\author{
Melanie O’Brien \\ ARC Centre of Excellence in Policing and Security, Griffith University
}

\begin{abstract}
Allegations of criminal conduct have been made against UN peacekeeping personnel. While only a small number commit criminal offences, these personnel must be held accountable for their actions. Ensuring accountability is difficult due to jurisdictional issues, including in which jurisdiction (host state, sending state, or third state) to prosecute offenders. However, the possibility of the International Criminal Court exercising jurisdiction over peacekeeping personnel (civilian or military) has not really been considered. This article will examine the potential applicability of the substantive law of war crimes and crimes against humanity under the Rome Statute to crimes committed by peacekeeping personnel.
\end{abstract}

Key words: International Criminal Court (ICC); war crimes; crimes against humanity; peacekeepers; accountability; international humanitarian law

\section{Introduction}

Accountability of peacekeeping personnel for crimes committed whilst on mission is something that the UN has been struggling with in recent years. Allegations of misconduct amounting to criminal behaviour have increased awareness of the problem. Misconduct has included sexual exploitation and abuse, weapons trading, and gold smuggling. ${ }^{1}$ Progress has been made in developing the UN's administrative investigative

\footnotetext{
${ }^{1}$ For sexual exploitation and abuse, see Special measures for protection from sexual exploitation and sexual abuse, Report of the Secretary General, U.N. Doc. A/59/782 (2005), U.N. Doc. A/60/861 (2006), U.N. Doc. A/61/957 (2007), U.N. Doc. A/62/890 (2008), U.N. Doc. A/63/720 (2009), U.N. Doc. A/64/669 (2010), U.N. Doc. A/65/742 (2011). For gold smuggling and weapons trading, see, e.g., (Plaut, 2008).
} 
capabilities, ${ }^{2}$ but the UN has no jurisdiction to conduct criminal investigations and prosecutions. Criminal investigation and prosecution is left up to states, such as the host state, the troop or police contributing state, and/or possibly a third state. The General Assembly has endorsed and encouraged states to enact their criminal jurisdiction, ${ }^{3}$ and troop contributing countries are granted exclusive jurisdiction over their military personnel in the mission Memorandum of Understanding. ${ }^{4}$ Indeed, domestic jurisdiction should be the first option for prosecution of any crimes committed by peacekeeping personnel, provided that the state in question has adequate substantive legislation to cover the crimes committed, and that the state's law permits extra-territorial application of such legislation. ${ }^{5}$ However, unfortunately not all states have the legislative means to prosecute, ${ }^{6}$ and not all states take action to prosecute criminal conduct by their peacekeepers. State prosecution of peacekeepers for crimes has been few and far between. Confirmed cases of prosecution include the Canadian cases prosecuting nine defendants for torture and murder of a Somalian teenager; ${ }^{7}$ and the US case of Ronghi, found guilty of raping and murdering a ten-year-old girl in Kosovo. ${ }^{8}$ Yet UN statistics

\footnotetext{
${ }^{2}$ Reports of the Secretary-General, ibid.

${ }^{3}$ U.N. Doc. A/RES/61/29 (2006); U.N. Doc. A/RES/61/291 (2007); U.N. Doc. A/RES/62/63 (2008); U.N. Doc. A/RES/63/119 (2008).

${ }^{4}$ Revised draft model memorandum of understanding between the UN and [participating state] contributing resources to [the UN peacekeeping operation], U.N. Doc. A/61/494 (2006); Report of the Special Committee on Peacekeeping Operations and its Working Group on the 2007 resumed session, U.N. Doc. A/61/19 (Part III) (2007); Comprehensive review of the whole question of peacekeeping operations in all their aspects, U.N. Doc. A/RES/61/291 (2007).

${ }^{5}$ For example, members of the United States Armed Forces are subject to the Uniform Code of Military Justice (UCMJ), which specifically states that it applies "in all places"; 10 U.S.C. § 805. Art. 5, but there is no legislative provision proscribing e.g. sexual exploitation.

${ }^{6}$ See e.g. Criminal accountability of United Nations officials and experts on mission, Report of the Secretary-General, U.N. Doc. A/66/174 (2011), for information on national jurisdiction over crimes of a serious nature committed by their nationals while serving on mission.

7 Report of the Somalia Commission of Inquiry, The Courts Martial, available online at http://www.forces.gc.ca/somalia/vol1/v1c14e.htm (last accessed 8 February 2012).

${ }^{8}$ United States v. Ronghi, No. ARMY 20000635, (A. Ct. Crim. A. May 27, 2003); United States v. Ronghi, 60 M.J. 83, 86 (C.A.A.F. 2004).
} 
and non-governmental organisation (NGO) reports demonstrate the number of offences committed by peacekeepers is far greater than these few prosecutions. For example, various NGOs have reported allegations of many cases of crimes including human trafficking, protection of brothel owners from raids, and sexual slavery, including of girls (Vandenberg, 2002; Amnesty International, 2004b; Mendelson, 2005; Save the Children, 2006). The Secretary-General's reports on sexual exploitation and abuse show that allegations of criminal conduct including rape, sexual assault, and sex with minors reached as high as 357 in 2006, and still 85 allegations in $2010 .^{9}$ These reports indicate that of the cases referred to states, few states respond to the referrals, and those that do rarely result in disciplinary action. It is also unclear from the UN reports what disciplinary action is taken, including whether or not prosecutions are held for criminal conduct. ${ }^{10}$ Due to the lack of transparency in these reports, and the lack of willingness of the UN to provide the public with details of allegations referred, it is not possible to follow up these referrals to determine the outcome. In addition to the ongoing problem of sexual exploitation and abuse, there have been reports of crimes such as corruption, gold smuggling and supplying weapons to disarmed rebels (Lynch, 2001; Plaut, 2008; Hogg, 2011).

For crimes committed by peacekeeping personnel within the jurisdiction of the host state (e.g. civilian UN staff), it is usually not possible for the host state to undertake investigation and prosecution. Peacekeeping missions operate in climates of armed conflict or post-conflict, in states or regions where there is little to no rule of law, and the law and order structure has collapsed.

With this apparent lack of willingness or ability of states to prosecute their peacekeeping personnel for criminal conduct, there is a need to consider another forum for prosecution. Should the crimes amount to international crimes, a potential forum is the International Criminal Court (ICC). The ICC is a court of last resort, available to

\footnotetext{
${ }^{9}$ Special measures for protection from sexual exploitation and sexual abuse, Report of the Secretary General, UN Docs A/58/777 (2004); A/59/782 (2005); A/60/861 (2006); A/61/957 (2007); A/62/890 (2008), (A/63/720) (2009), (A/64/669) (2010), (A/65/742) (2011).

${ }^{10}$ See e.g. UN Doc (A/65/742) (2011), para. 13, p. 6.
} 
prosecute international crimes when states are unwilling or unable to do so. ${ }^{11}$ There are many jurisdictional concerns to address when determining the potential of the ICC as a forum in which to prosecute peacekeeping personnel. This article will assume that preconditions to the exercise of jurisdiction by the ICC under Article 12 and issues of admissibility under Article 17 of the Rome Statute are met, and will examine some of the substantive law complications that may arise. ${ }^{12}$

The possibility of a crime by a peacekeeper falling within the definition of genocide will not be addressed, as it is considered highly unlikely that a peacekeeper will engage in genocide. This is based on two premises, the first being that peacekeeping personnel seldom find themselves located in the region of genocide- although this may occur, such as the UN Mission in Rwanda (UNAMIR) and the African-Union-UN Hybrid Operation in Darfur (UNAMID). ${ }^{13}$ The second and principal reason is that genocide requires a mental element of specific intent (Schabas, 2001) to destroy a group in whole or in part, the dolus specialis (Cassese, 2002b, 2008: 137; Schabas, 2008; Werle, 2009: 274-281). ${ }^{14}$ It is unlikely that a peacekeeper would have this intent; given the lack of connection a peacekeeper would have with the group in question- there is no history for a peacekeeper to have developed a discriminatory hatred of a group to the extent of forming intent to destroy that group in whole or in part. Genocidal situations exist in circumstances of years of inter-group animosity, discrimination and hatred, for example the years of 'Aryan race' domination intention of Hitler before and during World War II (Triffterer,

\footnotetext{
${ }^{11}$ Article 17, Rome Statute of the International Criminal Court, 2187 UNTS 90, entered into force 1 July 2002.

12 Article 12 requires that a crime be committed within the territory of a state party or by a national of a state party. Article 17 determines that a case is not admissible if it has been investigated and/or prosecuted by a state, if the person in question has already been tried for the same conduct, and if the case is not of sufficient gravity.

${ }^{13}$ Out of 63 missions past and present, only a handful have taken place in the context of what has been termed (sometimes controversially) genocide, such as Rwanda, the former Yugoslavia and Sudan. The ICTY and ICTR have convictions for genocide; e.g. Prosecutor v. Krstić, Trial Judgment, Case No. IT-9833-T, 2 August 2001; Prosecutor v. Akayesu, Trial Judgment, Case No. ICTR-96-4-T, 2 September 1998.

${ }^{14}$ Art. 6 Rome Statute; Akayesu, Trial Judgment, supra note 13, II 498.
} 
2001: 400-1). In contrast, a crime such as rape is committed for reasons of power and sexual satisfaction (MacKinnon, 1987: 85-92). ${ }^{15}$

However, if a peacekeeper commits a crime, could it amount to a war crime or a crime against humanity? This article will examine the chapeau elements of war crimes and crimes against humanity, in the context of crimes committed by peacekeeping personnel, pointing out problematic areas that may arise for their prosecution. While the individual elements of crimes are important, so are the unique chapeau elements of crimes under the Rome Statute. These chapeau elements are what demonstrate the difference of international crimes- namely, elements of crimes being committed on a large-scale, systematically, or part of a plan or policy- as opposed to basic domestic crimes. ${ }^{16}$ However, it is important to note that this is not necessarily the case with war crimes, as a single occurrence of a war crime is still considered an international crime. Yet a war crime is still considered an international crime because, along with genocide, crimes against humanity and aggression, a war crime shocks the conscience of humanity, committed against the world community as a whole, constituting a threat to international peace and security (Bassiouni, 2003: 119, 121).

A principle of peacekeeping is to 'do no harm': 'It is the duty of each peacekeeper to protect the vulnerable and to refrain from doing harm, ${ }^{17}$ Peacekeepers have a duty of care to the people they are sent to protect. ${ }^{18}$ In a letter to the General-Assembly in 2005, then Secretary-General Kofi Annan, referring to sexual exploitation and abuse by peacekeepers, found that 'such abhorrent acts are a violation of the fundamental duty of

\footnotetext{
${ }^{15}$ Prosecutor v. Sesay, Kallon and Gbao (RUF Case), Trial Judgment, Case No. SCSL-04-15-T, 2 March 2009, II 1348.

${ }^{16}$ The chapeau elements of the crimes under the Rome Statute are those elements that apply to all crimes in that category (genocide, war crimes or crimes against humanity). Therefore, in addition to the individual elements of the crime (e.g. the killing of a person for the crime of murder), the chapeau elements, which demonstrate organised, mass violence, must also exist and be proven. It is these elements that render the crimes 'international', in contrast with 'ordinary' domestic crimes. See e.g. (Werle, 2009: 141, II 375).

17 The Peacekeepers' Duty of Care; see www.un.org/en/peacekeeping/publications/yir/2005/duty_of_care.htm (last accessed 8 February 2012); MINURSO’s Conduct \& Discipline/Welfare newsletter, Vol. I, Issue I, March 2007.

${ }^{18}$ Ibid.
} 
care that all United Nations peacekeeping personnel owe to the local population' ${ }^{19}$ Criminal behaviour conducted by peacekeepers also creates problems with the potential success of a mission. Cooperation with and support of the local population are vital elements of a peace support mission, and 'the sexual exploitation scandals... have created additional distrust among the local population towards male peacekeepers' (Martin, 2005: 7). Acceptable conduct must be exercised by mission personnel at all times to ensure the best possible relations with local communities, which in turn contributes towards the effectiveness of the mission (McCoubrey and White, 1996: 177). ${ }^{20}$ Misconduct by members of a mission may also affect morale and effectiveness of the mission units. A vital aspect of a military force is its cohesiveness, obtained through values such as trust and heightened through camaraderie and high morale (Sagala, 2006: 59). ${ }^{21}$ Negative behaviour by troops, as well as negative assertions and attitudes towards the mission from both within and without the operation reduce the ability of troops to function effectively together (Sagala, 2006).

Thus criminal conduct by mission personnel can affect international peace and security through jeopardising the mission itself. This demonstrates the importance of ensuring accountability for such conduct, and validates the ICC as an appropriate forum in which to consider the prosecution of peacekeeping personnel for international crimes.

\section{Crimes against humanity}

There are two chapeau elements of a crime against humanity, which must be proven in addition to the individual elements of crimes. These chapeau elements are likely to be the principal reason why it would be very difficult to charge a peacekeeper with crimes against humanity. The chapeau elements concern the context of the crimes committed.

Unlike war crimes, what is not required is a nexus with armed conflict (Cassese, 2002a: 356; Meron, 1999: 49). The removal of this nexus is a departure from the

\footnotetext{
${ }^{19}$ Letter dated 24 March 2005 from the Secretary-General to the President of the General Assembly, U.N. Doc. A/59/710 (2005).

${ }^{20}$ See also The Peacekeeper's Duty of Care, supra note 17.

21 'Military organizational effectiveness should encompass social structure... non-material factors (esprit, staying power, and will to fight), and... morale and political attitudes...'; (Sagala, 2006: 59).
} 
definition of crimes against humanity under the Nuremberg Tribunal Statute (McCormack and Robertson, 1999: 652-3). Such as nexus was not included in the definition of crimes against humanity of the ad hoc tribunals. ${ }^{22}$ The lack of a nexus to armed conflict has been considered by the ICTY as to be the current formulation of customary international law, ${ }^{23}$ and that is reflected in the Rome Statute (Rückert and Witschel, 2001: 71; von Hebel and Robinson, 1999: 92-3). Rather than associating them with armed conflict, crimes against humanity may be viewed as a violation of human rights on a massive scale (Cassese, 2008: 99).

\subsection{Widespread or systematic attack direct against civilian population}

The first chapeau element of crimes against humanity is the crime is committed as part of a widespread or systematic attack directed against a civilian population. The words 'widespread' and 'systematic' are disjunctive, meaning that the crime must be committed as part of either a widespread attack or a systematic attack directed against a civilian population (Cassese, 2002a: 366, 2008: 99; Dixon and Hall, 2008: 176-8; Meron, 1999: 50; Robinson, 2001: 63; von Hebel and Robinson, 1999: 94-5). ${ }^{24}$ 'Widespread' is not a reference to geographical location, but to the number of victims (Dixon and Hall, 2008: 178). The ad hoc tribunals have given the term an expansive definition covering 'the large-scale nature of the attack and the number of targeted persons'. ${ }^{25}$

\footnotetext{
${ }^{22}$ Art. 5 ICTY Statute, Art. 3 ICTR Statute, Art. 2 SCSL Statute, Art. 5 Law on ECCC.

${ }^{23}$ Tadic, Trial Judgment, Case No. IT-94-1-T, 7 May 1997, II 627.

${ }^{24}$ RUF Case, supra note 15, II 78; Decision Pursuant to Article 15 of the Rome Statute on the Authorization of an Investigation into the Situation in the Republic of Kenya (Kenya investigation decision), ICC-014/09, P.T.Ch.II, 31 March 2010, II 94.

25 Prosecutor v. Kordic, Appeal Judgment, Case No. IT-95/14/2-A, 17 December 2004, II 94. See also Prosecutor v. Blaskic, Appeal Judgment, Case No. IT-95-14-A, 29 July 2004, II 101; Prosecutor v Kunarac et al (Foca), Appeal Judgment, Case No. IT-96-23 \& IT-96-23/1-A, 12 June 2002, II 94. The ICTR has used almost identical language: 'the scale of the attacks and the multiplicity of the victims'; Prosecutor v. Muyunyi, Trial Judgment, Case No. ICTR-00-55A-T, 12 September 2006, II 512; Prosecutor v. Muhimana, Trial Judgment, Case No. ICTR-95-1B-T, 28 April 2005, If 527; Prosecutor v. Semanza, Trial Judgment, Case No. ICTR-97-20-T, 15 May 2003, II 329; Prosecutor v. Musema, Appeal Judgment, Case No. ICTR96-13-A, 27 January 2000, III 203-4. See also Katanga and Chui, Decision on the confirmation of charges, ICC-01/04-01/07, 30 September 2008, II 394; Kenya investigation decision, supra note 24, II 95.
} 
A systematic attack is one with 'organised nature of the acts of violence and... improbability of their random occurrence', showing 'patterns of crimes, in the sense of the non-accidental repetition of similar criminal conduct on a regular basis'. ${ }^{26}$ Other courts and tribunals have held that the term 'reflects the organised nature of the attack, excludes random violence, and does not require a policy or plan' (Marston Danner, 2001: 474). ${ }^{27}$ However, under Art. 7(2)(a) of the Rome Statute, the attack must be 'pursuant to or in furtherance of a State or organizational policy to commit such an attack'. The Court has interpreted this to mean that while the policy does not have to be explicitly defined, the attack 'must... be thoroughly organised and follow a regular pattern', and 'also be conducted in furtherance of a common policy involving public or private resources'. ${ }^{28}$

It is only the attack that must be widespread or systematic. ${ }^{29}$ The criminal behaviour of the accused may be a single act or limited number of acts occurring in the context of the attack against a civilian population, and cannot be isolated, limited or random. ${ }^{30}$ The targeted civilian population must also be specified. In the RUF Case, the SCSL examined whether the killing of peacekeeping personnel fell within the scope of crimes against humanity. Trial Chamber I held that 'the attacks against UNAMSIL personnel were geographically and temporally removed from the crimes against civilians' found proven under other charges in the case. ${ }^{31}$ It was found that the peacekeeping personnel were not killed in connection with these other crimes or further crimes against civilians. The categorisation of the peacekeeping personnel was actually distinguished from the

${ }^{26}$ Kordic, Appeal Judgment, supra note 25, II 94; Blaskic, supra note 25, Appeal Judgment, II 101; Foca, Appeal Judgment, supra note 25, II 96; RUF Case, supra note 15, II 78. See also Katanga and Chui, confirmation of charges, supra note 25, III 394, 397; Kenya investigation decision, supra note 24, II 96.

${ }^{27}$ Muyunyi, Trial Judgment, supra note 25, II 512; RUF Case, supra note 15, II 79.

${ }^{28}$ Katanga and Chui, confirmation of charges, supra note 25, II 396; Kenya investigation decision, supra note 24, II 84.

${ }^{29}$ Kordic, Appeal Judgment, supra note 25, II 94; Blaskic, Appeal Judgment, supra note 25, II 101; Foca, Appeal Judgment, supra note 25, II 96.

${ }^{30}$ Ibid.; Tadic, Trial Judgment, supra note 23, II 649; Prosecutor v Jean-Pierra Bemba Gombo, Decision Pursuant to Article 61(7)(a) and (b) of the Rome Statute on the Charges of the Prosecutor Against JeanPierre Bemba Gombo (Bemba charges decision), ICC-01/05-01/08, P.T.Ch.II, 15 June 2009, III 77 and 81; Kenya investigation decision), supra note 24, IITI 81 and 85.

${ }^{31}$ RUF Case, supra note 15, II 1952. 
civilians of Sierra Leone- they were civilian peacekeeping personnel, but not the civilian population that was the target of the widespread or systematic attack. ${ }^{32}$ Thus, despite the fact that the peacekeeping personnel were held to be civilians, the Trial Chamber held that the attacks were 'distinct from and did not form part of the widespread or systematic attack on the civilian population of Sierra Leone'. ${ }^{33}$

Whether a crime committed by a peacekeeper was part of a widespread or systematic attack would depend upon the circumstances in which the crime was committed. ${ }^{34}$ If widespread or systematic crimes are ongoing, then a crime committed by a peacekeeper could be seen to be part of that attack on the civilian population. It is highly unlikely that a peacekeeper would intend their crime to be part of the attack, but it would certainly be committed as part of the attack if that attack is extant. ${ }^{35}$ It is also unlikely that a peacekeeper would commit a crime against humanity. This is due to the fact that peacekeeping missions do not generally take place in the context of a widespread or systematic attack on a civilian population. This does not mean they cannot take place in such a context: Rwanda (UNAMIR) and Sudan (UNMIS, UNAMID) are examples of missions that were or are located in territories experiencing widespread or systematic attacks on a civilian population. However the greatest difficulty in determining a crime by a peacekeeper to constitute a crime against humanity lies in the fact that crimes by peacekeeping personnel 'tend to be isolated and sporadic acts of military indiscipline or indifference', rather than part of a widespread or systematic attack (Maogoto, 2000: 74).

In the instance of a mission located in a post-conflict territory no longer experiencing a widespread or systematic attack on a civilian population, a crime committed by a peacekeeper could not be considered a crime against humanity, because it would not fulfil the first chapeau element. Unlike the definition of war crimes, in which a war crime is committed in the context of and associated with an armed conflict, a crime against humanity must be committed as part of the widespread or systematic attack. This

\footnotetext{
${ }^{32}$ Ibid. IIII 1953-4.

${ }^{33}$ Ibid. II 1953.

${ }^{34}$ The attack does not have to be a military attack. Elements of Crimes Art. 7 Introduction II 3; (Robinson, 2001: 74).

${ }^{35}$ Elements of crimes against humanity, infra.
} 
difference in wording demonstrates that the war crimes nexus with armed conflict is broader than the crimes against humanity nexus with an attack. A crime committed by a peacekeeper would have to be analysed in its context, and an isolated incident would not amount to a crime against humanity (Cassese, 2002a: 361). A crime committed after the cessation of the widespread or systematic attack does not constitute a crime against humanity (depending on the circumstances, it may constitute a war crime), because the emphasis of the crime would then be on the victim as an individual, rather than the victim as part of a collective, which is the essence of a crime against humanity. ${ }^{36}$ The victim would not be chosen because of their 'membership of a targeted civilian population', and therefore the crime committed would constitute an isolated incident, but not a crime against humanity. ${ }^{37}$

\subsection{Knowledge of or intention that conduct was part of widespread or}

\section{systematic attack}

The second chapeau element of crimes against humanity is that the perpetrator knew that the conduct was part of or intended the conduct to be part of a widespread or systematic attack against a civilian population (von Hebel and Robinson, 1999: 98). Knowledge of the attack does not require 'proof that the perpetrator had knowledge of all characteristics of the attack or the precise details of the plan or policy of the State or organisation' (Cassese, 2008: 115; Robinson, 2001: 72). ${ }^{38}$ Indeed the majority of peacekeeping personnel would not be aware of the details of a plan or policy of a widespread or systematic attack, as they would not be interacting directly with those who were organising the plan or policy. However it is something that those in superior positions within the mission may well be aware of, given their role in interacting directly with any leaders or commanders of parties to the conflict or other relevant groups. This was the case for General Dallaire in Rwanda prior to and following the commencement

\footnotetext{
${ }^{36}$ Tadic, Trial Judgment, supra note 23, Il 644.

${ }^{37}$ Ibid.

${ }^{38}$ Paragraph 2 of the Introduction to Art. 7 of the Elements of Crimes; Katanga and Chui, confirmation of charges, supra note 25, II 401.
} 
of the 1994 Rwandan genocide. ${ }^{39}$ Thus a Head of Mission, Force Commander and immediate deputies would be aware of the existence of a widespread or systematic attack including aspects of a plan or policy.

What the perpetrator must know are the factual circumstances- that there is an attack on a civilian population, and that his/her acts formed part of that attack (Cassese, 2002a: 365). ${ }^{40}$ The perpetrator's knowledge of the attack and awareness that his/her conduct formed part of that attack can be determined from the contextual circumstances, such as the accused's position in the military hierarchy, his presence at the scene of the crimes, and the general historical and political environment in which the acts occurred. ${ }^{41}$ The identification of such knowledge would be similar to the knowledge of armed conflict, and would be ascertained from the context of the commission of the crimes as well as the context (including the mandate) of the peace operation itself. The commission of crimes against humanity, an attack on a civilian population, would be the reason behind the decision of the Security Council to establish a peace mission, and therefore the very reason personnel are present in that territory. Personnel would be made aware of the situation on the ground, and the general historical and political environment, thus making it very difficult to argue they had no knowledge of an attack on a civilian population and that their act was part of that widespread or systematic attack. ${ }^{42}$

The requirement of knowledge or intention is disjunctive, indicating that a perpetrator may commit a crime without the intention that such conduct be part of the widespread or systematic attack. ${ }^{43}$ However, should they have knowledge of the attack, even without that specific intent, the perpetrator will still be found guilty of committing a crime against humanity if their crime is committed in the context of the attack.

\footnotetext{
${ }^{39}$ In January 2004 Dallaire testified at the trial of Bagosora, the 'mastermind' of the genocide; Prosecutor $v$ Bagosora, Trial Judgment, Case No. ICTR-98-41-T, 18 December 2008, II 181 fn. 200.

${ }^{40}$ Katanga and Chui, confirmation of charges, supra note 25, II 401; Kordic, Appeal Judgment, supra note 25, II 99; Blaskic, Appeal Judgment, supra note 25, II 124; Semanza, II 332; Tadic, Trial Judgment, supra note 23, II 657; Prosecutor v. Tadic, Appeal Judgment, Case No. IT-94-1-A, 15 July 1999, II 266.

${ }^{41}$ Katanga and Chui, confirmation of charges, supra note 25, II 402.

${ }^{42}$ Prosecutor v. Kayishema and Ruzidana, Judgment and Sentence, Case No. ICTR-95-1-T, 21 May 1999, IIII 133-4.

${ }^{43}$ Of course they would still require the general intent to commit the crime; Art. 30 Rome Statute.
} 


\section{War crimes}

\section{1 'Part of a plan or policy or part of a large-scale commission of such crimes'}

Under Article 8(1) of the Rome Statute there is no absolute requirement that a war crime be committed on a large-scale. Article 8(1) states that the 'Court shall have jurisdiction in respect of war crimes in particular when committed as part of a plan or policy or as part of a large-scale commission of such crimes' (emphasis added). The Prosecutor has accurately acknowledged that ' $[\mathrm{t}] \mathrm{his}$ threshold is not an element of the crime, and the words 'in particular' suggest that this is not a strict requirement' (Meron, 1999: 52; Rowe, 2004: 205-6) ${ }^{44}$ In its statutory interpretation of Article 17(1)(d) in the Ntaganda Arrest Warrant Appeal, the Appeals Chamber confirmed this interpretation of the Rome Statute, declaring that 'the requirement of either large-scale commission or part of a policy is not absolute but qualified by the expression 'in particular"' (von Hebel and Robinson, 1999). ${ }^{45}$ It should be perceived as a guideline rather than a requirement (von Hebel and Robinson, 1999: 124). Therefore a single occurrence of a war crime is sufficient for the ICC to establish jurisdiction. ${ }^{46}$ The expression 'in particular' indicates that the Court will have jurisdiction over all war crimes, but especially when committed as part of a plan or policy or large-scale commission, as such large-scale or policy commission is a significant factor in defining crimes as international, at which point they amount to a threat to international peace and security. However, the fact that this is not a requirement will enable the Court to prosecute single war crimes, or war crimes not

\footnotetext{
${ }^{44}$ Prosecutor's communication response to communications concerning the situation in Iraq (9 February 2006) (Iraq Communication), available at www.icc-cpi.int.

${ }^{45}$ Prosecutor v Ntaganda, Judgment on the Prosecutor's appeal against the decision of Pre-Trial Chamber I entitled 'Decision on the Prosecutor's Application for Warrants of Arrest, Article 58', Appeals Chamber, ICC-01/04, 13 July 2006 (Ntaganda Arrest Warrant Appeal), II 70. It is clear that the intention of drafters was not to render 'part of a plan or policy or part of a large-scale commission' as an absolute requirement as they specifically chose the wording 'in particular when committed...' over 'only when committed as part of...' (emphasis added); (von Hebel and Robinson, 1999: 108).

${ }^{46}$ This does not, however, avoid some scholars arguing that the plan or policy or large-scale commission should be an essential element of all international crimes, including war crimes: (May, 2005: 80-95); (Heller, 2009: 4-9).
} 
committed as part of a plan or policy or on a large-scale, and this will broaden the scope of potential crimes the Court can prosecute. In terms of crimes committed by peacekeepers, it has been shown above the difficulty that will arise in proving a peacekeeper's crime to be a crime against humanity due to the necessity for the crime to be part of a widespread or systematic attack. A war crime avoids any similar requirement, and thus it will be far more likely that a crime by a peacekeeper is classified as a war crime.

With regard to the number of victims (large-scale commission), the ICTR has distinguished the number of victims as an element specific to crimes against humanity only. In Semanza, ${ }^{47}$ the ICTR held that the number of victims was an integral element of a crime against humanity, but not of genocide. The Chamber held that genocide was a crime with 'no numeric minimum of victims', but that the number of victims could be used as an aggravating factor in sentencing. ${ }^{48}$ The same principle should apply to war crimes, given that it is not a requirement under the Rome Statute that a war crime be committed as part of a large-scale commission of such crimes.

It is unlikely that crimes such as sexual exploitation by peacekeeping personnel will be committed as part of a plan or policy, although in some circumstances it could be argued that there is a plan to commit these crimes. Such circumstances would include the involvement of multiple peacekeeping personnel in the trafficking and sexual slavery of women, of peacekeeping personnel who engage in protection of brothel owners in order to be able to make use of the brothel's services, or of peacekeeping personnel in gold smuggling or weapons trading (2004b; Plaut, 2008). While this would also be an issue with regards to the category of criminal responsibility (e.g. it may be viewed as joint commission $^{49}$ ), the context of the commission of the crime(s) can also be used to argue the existence of a plan to commit the crime(s).

While crimes committed by peacekeeping personnel may be isolated incidents, they can be placed in the broader context, and thus be committed as part of a large-scale

\footnotetext{
${ }^{47}$ Semanza, Trial Judgment, 15 May 2003.

${ }^{48}$ Ibid. In Krstić, Trial Judgment, supra note 13, the ICTY also referred to the number of victims as a factor in assessing the gravity of crimes committed, for sentencing; II 702.

${ }^{49}$ Art. 25(3)(a) Rome Statute.
} 
commission of war crimes. This will be the case if other crimes committed within the relevant territory are taken into account, as the armed conflict in the territory within which the peacekeeping personnel are situated is the context of crimes committed by peacekeeping personnel. The cessation of hostilities does not necessarily mean the end of the application of international humanitarian law, and thus does not mean the end of a situation of armed conflict. Thus, even crimes committed by peacekeeping personnel arriving after the cessation of hostilities can still be considered to be associated with the armed conflict, and therefore part of any large-scale commission of crimes that may have occurred during such conflict.

\subsection{Nexus with armed conflict}

To qualify as a war crime, conduct must be associated with the armed conflict, and the perpetrator needs to commit the crime in the context of an armed conflict and be aware of the existence of such conflict (Bothe, 2002: 388-9). ${ }^{50}$ Reference may be made to the jurisprudence of the ad hoc tribunals. Armed conflict was defined by the ICTY in Tadic as existing

whenever there is a resort to armed force between States or protracted armed violence between governmental authorities and organized armed groups or between such groups within a State. International humanitarian law applies from the initiation of such armed conflicts and extends beyond the cessation of hostilities until a general conclusion of peace is reached; or, in the case of internal conflicts, a peaceful settlement is achieved. Until that moment, international humanitarian law continues to apply in the whole territory of the warring States or, in the case of internal conflicts, the whole territory under the control of a party, whether or not actual combat takes place there. $^{51}$

\footnotetext{
${ }^{50}$ Art. 8 Rome Statute; Elements of Crimes, Doc. ICC-ASP/1/3.

${ }^{51}$ Prosecutor v. Tadic, Decision on Defence Motion for Interlocutory Appeal on Jurisdiction, Case No. IT94-1-AR72, 2 October 1995, II 70.
} 
The Tribunal's Appeals Chamber found it to be 'sufficient that the alleged crimes were closely related to the hostilities occurring in other parts of the territories controlled by the parties to the conflict'. 52

The association with armed conflict requirement of war crimes was also broadly interpreted by the ICTY in the Foca case:

[T] he criterion of a nexus with the armed conflict under Article 3 of the Statute does not require that the offences be directly committed whilst fighting is actually taking place, or at the scene of combat. Humanitarian law continues to apply in the whole of the territory under the control of one of the parties, whether or not actual combat continues at the place where the events in question took place. It is therefore sufficient that the crimes were closely related to the hostilities occurring in other parts of the territories controlled by the parties to the conflict. The requirement that the act be closely related to the armed conflict is satisfied if, as in the present case, the crimes are committed in the aftermath of the fighting, and until the cessation of combat activities in a certain region, and are committed in furtherance or take advantage of the situation created by the fighting. ${ }^{53}$

The phrase 'in the context of' is to be interpreted in 'very general geographical and temporal terms', following the direction of the ICTY, and 'associated with' demonstrates the nexus with the armed conflict (Dörmann et al., 2001: 121). The ICC has applied the broad interpretation, requiring that 'the armed conflict must play a substantial role in the perpetrator's decision, in his or her ability to commit the crime or in the manner in which the conduct was ultimately committed'. ${ }^{54}$ However, the 'armed conflict need not be

\footnotetext{
${ }^{52}$ Ibid. Crimes can still be 'committed in the context of an armed conflict, even if substantial clashes were not occurring in the region at the time and place that the crimes were allegedly committed'; Celebici, Trial Judgment, Case No. IT-96-21-A, 20 February 2001, IIII 196-7.

${ }^{53}$ Kunarac et al. (Foca), Trial Judgment, Case No. IT-96-23 and IT-96-23/1-A, 22 February 2001, II 568. 'There is no necessary correlation between the area where the actual fighting is taking place and the geographical reach of the laws of war. The laws of war apply in the whole territory of the warring states or, in the case of internal armed conflicts, the whole territory under the control of a party to the conflict, whether or not actual combat takes place there, and continue to apply until a general conclusion of peace or, in the case of internal armed conflicts, until a peaceful settlement is achieved.' Foca, Appeal Judgment, supra note 25, II 57. (Rowe, 2004: 208).

${ }^{54}$ Prosecutor v. Lubanga, Decision on the confirmation of charges, ICC-01/04-01/06 (29 January 2007), II 287; Katanga and Chui, confirmation of charges, supra note 25, IIII 380-382.
} 
considered the ultimate reason for the conduct and the conduct need not have taken place in the midst of battle'.55

Crimes committed by peacekeeping personnel may fall within this expansive interpretation. Peace support operations are located in places experiencing on-going conflict, or in a post-conflict situation. Their very presence is related to the armed conflict; that is precisely the reason the mission is in that territory. ${ }^{56}$ The commission of a crime such as sexual exploitation takes advantage of the situation created by the fighting, as the conflict has created a society in which women are left with no choice but to sell their bodies in order to survive. Weapons trading can flourish only due to parties engaging in armed conflict. Thus, it can be argued that these crimes are committed in the context of an armed conflict, and are associated with an armed conflict, even if hostilities have ceased. ${ }^{57}$

Unfortunately, such an application to UN missions is not so simple, and it may be the case that the Court finds that the crime(s) in question do not have a nexus to armed conflict because it was committed after the cessation of hostilities- or even later in time, after the conclusion of peace, and thus concludes there is no jurisdiction under Article 8. There is much debate on the issue of peacekeeping personnel involvement in armed conflict, and whether and when they are considered to be combatants engaging in armed conflict or civilians. ${ }^{58}$ There is no clear legal stance as to the application of IHL (Bialke, 2001; Faite and Grenier, 2004; Greenwood, 1998; Murphy, 2003; Palwankar, 1993); that is, the exact circumstances when peacekeeping personnel are considered to be engaging in armed conflict (2004a: 208-9). The Secretary-General's Bulletin on Observance by United Nations forces of international humanitarian law states that

\footnotetext{
55 Ibid.

${ }^{56}$ RUF Case, supra note 15, II 1889.

${ }^{57}$ It is not "necessary that the crime alleged takes place during combat, that it be part of a policy or of a practice officially endorsed or tolerated by one of the parties to the conflict, or that the act be in actual furtherance of a policy associated with the conduct of war or in the actual interest of a party to the conflict'; Tadic, Trial Judgment, supra note 23, đI 573.

58 States may be unwilling to concede that their personnel have engaged in armed conflict, as upon engagement in armed conflict, peacekeepers lose their special protection as civilians and become combatants; see Arts. 8(2)(b)(iii) and 8(2)(e)(iii) Rome Statute.
} 
The fundamental principles and rules of international humanitarian law set out in the present bulletin are applicable to United Nations forces when in situations of armed conflict they are actively engaged therein as combatants, to the extent and for the duration of their engagement. They are accordingly applicable in enforcement actions, or in peacekeeping operations when the use of force is permitted in self-defence. ${ }^{59}$

From this, it can be deduced that whether IHL is applicable will depend on the individual mandate of the operation, and this may assist in interpreting whether the circumstances in which the crime is committed amounts to armed conflict. In addition to the mandate, the SCSL has suggested other elements that may assist in defining the situation:

the specific operational mandates, the role and practices actually adopted by the peacekeeping mission during the particular conflict, their rules of engagement and operational orders, the nature of the arms and equipment used by the peacekeeping force, the interaction between the peacekeeping force and the parties involved in the conflict, any use of force between the peacekeeping force and the parties in the conflict, the nature and frequency of such force and the conduct of the alleged $\operatorname{victim(s)}$ and their fellow personnel. ${ }^{60}$

The RUF Case Trial Chamber held that 'peacekeeping personnel are considered to be civilians only insofar as... they do not take direct part in the hostilities' (Sivakumaran, 2010: 1026-29). ${ }^{61}$ It also held that 'their protection would not cease if the personnel use armed force only in exercising their right to individual self-defence [and that] the use of force by peacekeeping personnel in self-defence in the discharge of their mandate,

\footnotetext{
${ }^{59}$ Secretary-General's Bulletin on Observance by United Nations forces of international humanitarian law, U.N. Doc. ST/SGB/1999/13 (1999), sub-section 1.1. It must be recalled that the Bulletin is an internal UN document, which amounts to policy but there is disagreement as to whether it amounts to law. The Bulletin is binding on members of UN forces, but the source of the legal obligation stems from IHL rules that individual states are bound by. The Bulletin mostly applies customary rules of IHL, although some rules imposed by the Bulletin are not customary. Customary rules of IHL will of course apply, but beyond customary law, force personnel will still be bound by the law of their sending state, and states do not all apply the same rules of IHL, as not all states are members of all IHL treaties. (Faite and Grenier, 2004: 1011); (Shraga, 2000: 408-9); (Tittemore, 1997: 93); (McCoubrey and White, 1996: 161-2); (Rowe, 2000: $53)$.

${ }^{60}$ RUF Case, supra note 15, II 234. See also (Sivakumaran, 2010: 1026-29).

${ }^{61}$ RUF Case, supra note 15, II 233.
} 
provided that it is limited to such use, would not alter or diminish the protection afforded to peacekeeping personnel'. ${ }^{6}$

Whether or not IHL is applicable to peacekeeping personnel is not be relevant if it is the peacekeeper committing a war crime, as a war crime may be committed by a combatant or a civilian (Cassese, 2008: 82-3; Dinstein, 2010: 264; Dörmann et al., 2001: 119). A war crime must be committed in the context of and be associated with an armed conflict, but the perpetrator does not have to be engaged as a combatant in the armed conflict (Dörmann, 2002: 391-3; Zimmerman, 2008: 488). ${ }^{63}$ The applicability of IHL could simply be used to assist in determining armed conflict status.

A problem that would arise is whether to charge a peacekeeper with a war crime committed in international or non-international armed conflict, and again there is no clear rule on this (Faite and Grenier, 2004: 11; Greenwood, 1998: 8-9). ${ }^{64}$ Clearly if the mission is mandated to exist because of an armed conflict between two states, then the armed conflict is international. ${ }^{65}$ However, most missions are located in one state, due to internal armed conflict, usually between government and rebel or revolutionary forces (e.g. UN Mission in the Democratic Republic of Congo MONUC, UN Stabilization Mission in Haiti MINUSTAH). One argument is that such a conflict automatically becomes international with the involvement of a multi-national peacekeeping force (Faite and Grenier, 2004: 11; Kirsch, 1995: 105). The opposite claim is that an armed conflict is only international if it involves hostilities between two states; ${ }^{66}$ and a UN force is not a state (Greenwood, 1998: 15). ${ }^{67}$

\footnotetext{
${ }^{62}$ Ibid.

${ }^{63}$ Prosecutor v. Akayesu, Appeal Judgment, Case No. ICTR-96-4-A, 1 June 2001, IIII 443-5.

${ }^{64}$ Art. 8(2)(a) and (b) grant jurisdiction over crimes committed in international armed conflict; Art. 8(2)(c) and (e) grant jurisdiction over crimes committed in armed conflict not of an international character.

${ }^{65}$ Lubanga, confirmation of charges, supra note 54, II 209.

${ }^{66}$ McCoubrey and White state that 'there is no reason to think that the involvement of a UN force in a situation of armed conflict will of itself render the conflict 'international' for the purposes of the application of the jus in bello'; (McCoubrey and White, 1996: 172).

${ }^{67}$ Greenwood argues that because of its status as a subject of international law, the UN is subject to IHL 'insofar as it engages in activities of the kind regulated by IHL'; (Greenwood, 1998: 16).
} 
This issue was broached in the RUF Case. The Trial Chamber found the conflict in Sierra Leone to be non-international in nature, and examined whether the involvement of the Economic Community of West African States Monitoring Group (ECOMOG) force automatically rendered the armed conflict international. Unfortunately the Trial Chamber did not discuss this in depth, but held that the armed conflict remained non-international, because 'ECOMOG fought against the AFRC/RUF at the behest of the internationally recognised Kabbah Government'. ${ }^{68}$ Henceforth the 'intervention cannot be classed as recourse to armed force between two States'. ${ }^{69}$ The Trial Chamber reached this conclusion by applying the definition of international armed conflict found in common Article 2 of the Geneva Conventions, that international armed conflict exists whenever there is declared war or any other armed conflict between two or more High Contracting Parties, which in the case of the Geneva Conventions, limits international armed conflict to armed conflict between states (Sassoli and Bouvier, 1999: 89). ${ }^{70}$ However, Additional Protocol I recognises that Article 2 of the Geneva Conventions also includes 'armed conflicts in which peoples are fighting against colonial domination and alien occupation and against racist regimes in the exercise of their right of self-determination' 71

On strict application of the Geneva Conventions, the SCSL was correct in determining that the Sierra Leone conflict did not transform into an international one. However, there are two issues. Firstly, the ECOMOG force was not a UN force, but a force from West African States fighting under a mandate from Economic Community of West African States (ECOWAS). ${ }^{72}$ While it may have been a multi-national force, it was ultimately a regional multi-national force, and not a UN-mandated force, and thus there must be differentiation between the situations of the organisations involved and the mandates of

\footnotetext{
${ }^{68}$ RUF Case, supra note 15, II 973.

${ }^{69}$ Ibid.

${ }^{70}$ RUF Case, supra note 15, II 971. The ICTY Appeals Chamber has held it to be indisputable that an armed conflict is international if it takes place between two or more States'; Tadic, Appeal Judgment, supra note 40, II 84.

${ }^{71}$ Art. 1(4), Additional Protocol I.

${ }^{72}$ RUF Case, supra note 15, I 973.
} 
the forces. ${ }^{73}$ This would include the application of IHL to the mission forces and the extent of such application by the forces. ${ }^{74}$

Secondly, it is determined that IHL applies to UN forces when they are engaged in hostilities. While it is true that IHL has been determined to apply in both international and non-international armed conflicts, and there is support for the elimination of a distinction between the two (Cassese, 2008: 96; Crawford, 2007), ${ }^{75}$ a distinction does still exist between international and non-international armed conflict, particularly with regard to IHL. The application of IHL to UN forces demonstrates that there is consideration of the UN forces as engaging in international armed conflict (Greenwood, 1998: 25). Even if the UN forces are fighting at the request of a government, it cannot be said that they are engaging in non-international armed conflict because they do not form part of the government (or other) forces. UN forces are independent of all parties to any armed conflict; impartiality is one of the basic principles of peacekeeping. ${ }^{76}$ Therefore, a UN force is an international force which may become party to the conflict upon engagement in hostilities against any party to the conflict- and therefore the armed conflict becomes international.

The ICTY has held that an internal armed conflict 'may become international (or, depending upon the circumstances, be international in character alongside an internal armed conflict) if (i) another State intervenes in that conflict through its troops, or

\footnotetext{
${ }^{73}$ Although notably, the SCSL does not have jurisdiction over peacekeeping personnel under Art. 1(2) of its statute: 'Any transgressions by peacekeepers and related personnel present in Sierra Leone pursuant to the Status of Mission Agreement in force between the United Nations and the Government of Sierra Leone or agreements between Sierra Leone and other Governments or regional organizations, or, in the absence of such agreement, provided that the peacekeeping operations were undertaken with the consent of the Government of Sierra Leone, shall be within the primary jurisdiction of the sending State.'

${ }^{74}$ Zwanenburg points out 'the discrepancy between the attention for respect for international humanitarian law by operations under United Nations command, and 'subcontracted' operations like ECOMOG', with the UN applying minimum standards whereas ECOMOG did not; (Zwanenburg, 1999: 756).

${ }^{75}$ Tadic, Appeal on Jurisdiction, supra note 51, IIII 97-98.

${ }^{76}$ United Nations Peacekeeping Operations Principles and Guidelines (New York: Peacekeeping Best Practices Section, Division of Policy, Evaluation and Training, Department of Peacekeeping Operations, United Nations, January 2008), at 66-69, http://pbpu.unlb.org/pbps/Library/Capstone_Doctrine ENG.pdf, (last accessed 8 February 2012) (hereinafter 'DPKO Principles and Guidelines').
} 
alternatively if (ii) some of the participants in the internal armed conflict act on behalf of that other State. ${ }^{77}$ It may be argued that a state has intervened in the conflict through its troops, despite the fact that those troops are part of the UN-mandated mission. The ICTY determined that a test of control must be applied to determine whether individuals are acting on behalf of a state, and thus whether that renders the conflict international. Reference was made to the Nicaragua test, which requires that the 'State had effective control of the military or paramilitary operations in the course of which the alleged violations were committed'. ${ }^{78}$ The ICTY determined that the 'control required by international law may be deemed to exist when a State (or, in the context of an armed conflict, the Party to the conflict) has a role in organising, coordinating or planning the military actions of the military group, in addition to financing, training and equipping or providing operational support to that group. ${ }^{, 79}$ It seems that the ICTY has a lower threshold in determining this control, as the ICJ held that the US participation in financing, organising, training, supplying and equipping the contras, the selection of its military or paramilitary targets, and the planning of the whole operation was insufficient to attribute the acts of the contras to the US- that is, such participation did not amount to control. ${ }^{80}$ In contrast, such US participation would fall within the ICTY test for control.

In a peace operation, such control is shared between the sending state and the UN. ${ }^{81}$ Effective control is exercised over military personnel by the sending state and by the UN: for example, the sending state controls any disciplinary matters, but the UN is ultimately

\footnotetext{
${ }^{77}$ Tadic, Appeal Judgment, supra note 40, II 84; see also Lubanga, confirmation of charges, supra note 54, II 209.

${ }^{78}$ Military and Paramilitary Activities in and against Nicaragua (Nicaragua v. United States of America), Merits, Judgment of 27 June 1986, I.C.J. Reports 1986, at 14, II 115; Tadic, supra note 40, Appeal Judgment, II 100. Additional Protocol II also refers to 'responsible command' of armed forces or other organised armed groups; Art. 1(1).

79 This test is used when a state does not intervene directly; Tadic, Appeal Judgment, supra note 40, Ф 137; Lubanga confirmation of charges, supra note 54, II 210.

${ }^{80}$ Nicaragua, supra note 78, TII 115-6.

${ }^{81}$ DPKO Principles and Guidelines, supra note 76, at 66-69.
} 
in charge of the military actions of personnel on a mission. ${ }^{82}$ Personnel have been financed, trained and equipped by their sending states, but are also financed, trained and equipped by the UN whilst on a mission. ${ }^{83}$ National case law has also held that member states of the UN still retain their sovereignty when carrying out UN tasks and national personnel are still ultimately agents of the state, because the individual component forces [of a mission] have their own national duty and discipline and remain in their national service'. ${ }^{84}$ Therefore, given the fact that each sending state contributes significantly to 'organising, coordinating or planning the military actions of the military group, in addition to financing, training and equipping or providing operational support to that group', ${ }^{85}$ it could be argued that the armed conflict is international due to the involvement of each sending state through its troops, who remain agents of their sending state.

The Preparatory Commission of the Rome Statute specifically decided not to define 'international armed conflict' (Dörmann et al., 2001: 115), and thus it is open to interpretation by the Court. However, one inclusion has been added to the Elements of Crimes, in a footnote to Article 8(2)(a)(i), which states that 'international armed conflict' as it applies to all crimes under Article 8(2)(a) includes military occupation. ${ }^{86}$ This may help to clarify which provisions to charge under in some circumstances, as some

\footnotetext{
${ }^{82}$ However, this UN control may not be absolute in praxis, which in turn supports the argument that the state is in control of its personnel. States will still apply their own Rules of Engagement (ROE) to their national personnel, and also apply a distinct interpretation of the mission ROE; (Rowe, 2006: 227-8); (McCoubrey and White, 1996: 146).

${ }^{83}$ The UN also accepts responsibility for injuries or damage caused by mission personnel unjustifiably to innocent parties, with the exclusion of damage to persons or property resulting solely from military operations or military necessity; (Zwanenburg, 2005: 88-9); (Murphy, 2006: 539).

${ }^{84}$ House of Lords decision in Attorney-General v Nissan [1969] All ER 629: 647.

${ }^{85}$ Tadic, supra note 40, Appeal Judgment, II 137; Lubanga, confirmation of charges, supra note 54, II 210.

${ }^{86}$ The law of occupation has been applied by states in some missions, and such application has support. See, e.g., (Kelly, 1999); (Kelly et al., 2001); (Oswald, 2007); (Vité, 2004). There are, however, others that do not subscribe to the concept of occupation with regards to multi-national operations; see (Zwanenburg, 2005: 198-9).
} 
peacekeeping missions involve the UN acting as an occupying power. ${ }^{87}$ In such a situation, under the Rome Statute armed conflict would automatically be classified as international.

These arguments demonstrate that the situation is far from clear. The Prosecutor would not necessarily have to make a distinction with charges, as he already avoided doing in the Lubanga case. It is for the Court to determine this on the facts at the pre-trial stage (Rowe, 2004: 220-1 fn 102). The charges confirmed against Lubanga are those of enlisting and conscripting children under both Article 8(2)(b)(xxvi) (international armed conflict) and Article 8(2)(e)(vii) (non-international armed conflict). ${ }^{88}$ Charging crimes under both international and non-international was based on the fact that the Trial Chamber found there to be both types of armed conflict in existence at different periods of time. ${ }^{89}$

\subsection{Knowledge of existence of armed conflict and status of victim}

Finally, under Article 8, a perpetrator of a war crime must be aware of the existence of an armed conflict. The knowledge required is simply that of the existence of an armed conflict, and the perpetrator is not required to have any knowledge of the category of armed conflict (international or non-international) or the circumstances establishing the category of armed conflict (Bothe, 2002: 389; Dörmann et al., 2001: 122). It would be extraordinarily difficult for a peacekeeper to claim they were not aware of the existence of an armed conflict within the territory in which they are stationed. As stated above, the ultimate reason for the presence of a peace support operation within any territory is a

\footnotetext{
${ }^{87}$ For example, UNMIK, the UN Interim Administration Mission in Kosovo, both a civil and military presence in Kosovo; Security Council Resolution 1244, U.N. Doc. S/RES/1244 (1999). Rowe, however, asserts that it is 'unrealistic... to argue that the armed forces comprising the multinational force are in 'occupation' of the territory on which they are based'; (Rowe, 2006: 230). Yet during occupation, 'territory must be placed under the actual authority of the... army' and 'the authority of the legitimate authority [must have] passed into the hands of the occupant', and this is in fact what has occurred in peace support operations such as UNMIK; Regulations concerning the Laws and Customs of War on Land, Annex to the Hague Convention IV 1907, Arts. 42 and 43. See also Rowe's discussion in (Rowe, 2000: 54-6).

${ }^{88}$ Lubanga, confirmation of charges, supra note 54, II 410.

${ }^{89}$ Ibid. III 205- 237.
} 
situation of armed conflict or post-conflict. Even if granted a mandate, rules of engagement and weaponry consistent only with the ability to engage in hostilities in selfdefence, this does not result in a lack of awareness of circumstances amounting to armed conflict in the territory in which the mission is carrying out the mandate.

For some war crimes, ${ }^{90}$ the perpetrator must also be aware of the factual circumstances establishing the status (protected or civilian/non-combatant) of the victim. ${ }^{91}$ The status of the victim is to be either protected under one or more of the Geneva Conventions of 1949 (Article $8(2)(a)$ ) or is either hors de combat or a civilian, medical personnel or religious personnel taking no active part in the hostilities (Article 8(2)(c)). Protected persons are 'those who, at a given moment and in any manner whatsoever, find themselves, in case of a conflict or occupation, in the hands of a Party to the Conflict or Occupying Power of which they are not nationals'. 92 The elements of nationality and 'in the hands of' have been loosely applied by the ICTY, in order to avoid a too restrictive interpretation of the definition, particularly with regard to the number of non-international armed conflicts between parties of the same nationality. Thus a person may be granted protected status even if $\mathrm{s} / \mathrm{he}$ is the same nationality as the perpetrator. ${ }^{93}$ The Appeals Chamber decided that 'Article 4 intends to look to the substance of relations, not their legal characterisation as such'. ${ }^{94}$ With respect to 'in the hands of', the ICTY has referred to the International Committee of the Red Cross's Commentary on the Geneva Convention IV which expressly states that 'It is not merely a question of being in enemy hands directly, as a prisoner is... In other words, the expression 'in the hands of' need not necessarily be understood in the physical sense; it simply means that the person is in territory under the control of the Power in question'. ${ }^{95}$ Thus it is clear that the definition of a protected

\footnotetext{
${ }^{90}$ Those under Arts. 8(2)(a) and 8(2)(c).

${ }^{91}$ The perpetrator does not have to be aware 'of the protected status under the Geneva Conventions per se, which would be a question of law'- the emphasis is on the factual circumstances; (Dörmann et al., 2001: 118-9); (Bothe, 2002: 390).

92 Art. 4, Geneva Convention IV.

${ }^{93}$ Tadic, Appeal Judgment, supra note 40, II 166.

${ }^{94}$ Ibid. II 168.

${ }^{95}$ Prosecutor v. Rajic, Review of the Indictment Pursuant to Rule 61 of the Rules of Procedure and Evidence, Case No. ICTY-95-12-R61, 13 September 1996, II 36.
} 
person is a broad one, and will cover a prisoner of war, but also any person located in the territory in which armed conflict is taking place and in general which is under the control of a party to the conflict.

Again, the situation in which the mission is conducted will provide clear evidence of a person's non-combatant status. The relevant facts relating to each victim should be examined to ascertain whether, 'in each individual's circumstances, that person was actively involved in hostilities at the relevant time'. ${ }^{96}$ A peacekeeper would have trouble proving that they were not aware of the protected status of a young girl, or a woman working in a brothel, located within the territory under control of one or more parties involved in the armed conflict. Clearly the victims of sexual exploitation by peacekeeping personnel are not taking direct part in hostilities and therefore are not combatants (Melzer, 2009). ${ }^{97}$ Encompassed within this definition would also be former members of an armed force who have laid down their arms and are no longer taking part in hostilities (Zimmerman, 2008: 488). ${ }^{98}$

\section{Conclusion}

It is vital that any personnel serving on a peace support operation who engage in criminal conduct are held accountable for their actions. Such conduct jeopardises the effectiveness of the mission, but most importantly often results in harm committed to one or more victims. With regards to military personnel, troop contributing countries are granted exclusive jurisdiction. For civilian personnel (UN staff, experts on mission), host state and third state jurisdiction is applicable. However the lack of prosecutions undertaken by states of criminal misconduct by peacekeepers demonstrates there is a need for an alternate forum to be considered. If the circumstances of the crime fit, then the ICC should be such a forum, to fill the void of unwilling and/or unable states.

There are definitive challenges to prosecuting a peacekeeper for crimes against humanity in the ICC due to the chapeau elements. A charge of crimes against humanity would be infinitely more difficult than one under war crimes, due to the required

\footnotetext{
96 Tadic, Trial Judgment, supra note 23, II 616.

${ }^{97}$ Ibid. II 615.

${ }^{98}$ Tadic, Trial Judgment, supra note 23, II 616.
} 
elements of systematic or widespread attack. It would be a rare instance where the Court would find a peacekeeper committing a crime that constituted part of a systematic or widespread attack, but it is not inconceivable.

The potential application of the chapeau elements of war crimes to crimes committed by peacekeeping personnel offers more potential, but is not without complication. The determination of the existence of an armed conflict and the status of such a conflict are the two biggest hurdles. Ultimately, however, it would not be impossible to prosecute a peacekeeper under Article 8 of the Rome Statute. Once the existence of an armed conflict has been established, applying the broad interpretation of association with armed conflict established by the ICTY in the Foca case will enable the Prosecutor to argue that crimes committed by a peacekeeper are committed in the context of and are associated with an armed conflict, regardless of whether or not the peacekeeping personnel were engaged as combatants in that armed conflict.

For both categories of crimes, the contextual elements will be vital. The mandate of the mission, the Rules of Engagement, ${ }^{99}$ and the situation on the ground will all require analysis to determine whether there is a systematic or widespread attack, or an armed conflict. The principal complication will be whether a peacekeeper's crime can be linked to the attack or armed conflict. As has been demonstrated, there are potential situations in which these elements can be proven. The concept may present a challenge, but in absence of states taking prosecutorial action, peacekeeping personnel could be prosecuted for war crimes and crimes against humanity before the ICC.

\footnotetext{
${ }^{99}$ The Rules of Engagement (ROE) that ultimately govern any use of force. The Force Commander ultimately defines a mission's ROE, although national contingents will usually also implement their own. (Rowe, 2000: 59-62; McCoubrey and White, 1996: 146).
} 


\section{References}

2004a. Application of international humanitarian law and international human rights law to UN-mandated forces: Report on the Expert meeting on multinational peace operations. International Review of the Red Cross 86, 207-212.

2004b. Kosovo (Serbia and Montenegro) "So does it mean that we have the rights?" Protecting the human rights of women and girls trafficked for forced prostitution in Kosovo. Amnesty International.

2006. From Camp to Community: Liberia study on exploitation of children, Save the Children UK, Monrovia.

Bassiouni, M.C., 2003. Introduction to International Criminal Law. Transnational Publishers, Inc., Ardsley, New York.

Bialke, M.J.P., 2001. United Nations Peace Operations: Applicable Norms and the Application of the Law of Armed Conflict. A.F.L. Rev. 50, 1-63.

Bothe, M., 2002. War Crimes, in: Cassese, A., Gaeta, P., Jones, J.R.W.D. (Eds.), The Rome Statute of the International Criminal Court. Oxford University Press, Oxford, pp. $379-426$.

Cassese, A., 2002a. Crimes against Humanity, in: Cassese, A., Gaeta, P., Jones, J.R.W.D. (Eds.), The Rome Statute of the International Criminal Court. Oxford University Press, Oxford, pp. 353-378.

Cassese, A., 2002b. Genocide, in: Cassese, A., Gaeta, P., Jones, J.R.W.D. (Eds.), The

Rome Statute of the International Criminal Court. Oxford University Press, Oxford, pp. $335-352$.

Cassese, A., 2008. International Criminal Law, 2nd ed. Oxford University Press, Oxford.

Crawford, E., 2007. Unequal before the Law: The Case for the Elimination of the Disctinction between International and Non-international Armed Conflicts. Leiden Journal of International Law 20, 441-465.

Dinstein, Y., 2010. The Conduct of Hostilities Under the Law of International Armed Conflict, 2nd ed. Cambridge University Press, Cambridge. 
Dixon, R., Hall, C.K., 2008. Crimes against humanity- chapeau, in: Triffterer, O. (Ed.), Commentary on the Rome Statute of the International Criminal Court, 2nd ed. C.H. Beck, Hart, Nomos, Muenchen, Oxford, Baden-Baden.

Dörmann, K., 2002. Elements of War Crimes under the Rome Statute of the International Criminal Court: Sources and Commentary. Cambridge University Press, Cambridge.

Dörmann, K., La Haye, E., Von Hebel, H., 2001. The Context of War Crimes, in: Lee, R.S. (Ed.), The International Criminal Court: Elements of Crimes and Rules of Procedure and Evidence. Transnational Publishers, Inc., Ardsley, NY, pp. 112-123.

Faite, A., Grenier, J.L., 2004. Expert Meeting on Multinational Peace Operations: Applicability of International Humanitarian Law and International Human Rights Law to UN Mandated Forces. International Committee of the Red Cross, Geneva.

Greenwood, C., 1998. International Humanitarian Law and United Nations Military Operations. Yearbook of International Humanitarian Law 1, 3-34.

Heller, K.J., 2009. Situational Gravity under the Rome Statute, in: Stahn, C., von den Herik, L. (Eds.), Future Directions in International Criminal Justice. Cambridge University Press, Cambridge.

Hogg, J., 2011. UN employee suspected of smuggling Congo minerals, AlertNet. Reuters, http://www.trust.org/alertnet/news/un-employee-suspected-of-smuggling-congominerals/.

Kelly, M.J., 1999. Restoring and Maintaining Order in Complex Peace Operations: The Search for a Legal Framework Martinus Nijhoff Publishers, The Hague.

Kelly, M.J., McCormack, P.T.L.H., Oswald, B., Muggleton, P., 2001. Legal aspects of Australia's involvement in the International Force for East Timor. International Review of the Red Cross, 101-139.

Kirsch, P., 1995. The Convention on the Safety of United Nations and Associated Personnel. International Peacekeeping, 102-106.

Lynch, C., 2001. Misconduct, Corruption by U.S. Police Mar Bosnia Mission, The Washington Post, http://www.washingtonpost.com/ac2/wpdyn?pagename=article $\&$ contentId=A88992-2001 May28\&notFound=true . 
MacKinnon, C.A., 1987. Feminism Unmodified. Harvard University Press, Cambridge, Mass., London.

Maogoto, J.N., 2000. Watching the Watchdogs: Holding the UN Accountable for Violations of International Humanitarinan Law by the 'Blue Helmets'. Deakin Law Review 5, 47-80.

Marston Danner, A., 2001. Constructing a Hierarchy of Crimes in International Criminal Law Sentencing. Virginia Law Review 87, 415-501.

Martin, S., 2005. Must Boys be Boys? Ending Sexual Exploitation \& Abuse in UN Peacekeeping Missions. Refugees International, p. 32.

May, L., 2005. Crimes Against Humanity: A Normative Account. Cambridge University Press, Cambridge.

McCormack, T.L.H., Robertson, S., 1999. Jurisdictional Aspects of the Rome Statute for the New International Criminal Court. Melbourne University Law Review 23, 635666.

McCoubrey, H., White, N.D., 1996. The Blue Helmets: Legal Regulation of United Nations Military Operations. Dartmouth Publishing Company Limited, Aldershot.

Melzer, N., 2009. Interpretive guidance on the notion of direct participation in hostilities under international humanitarian law. International Committee of the Red Cross, Geneva.

Mendelson, S.E., 2005. Barracks and Brothels: Peacekeepers and Human Trafficking in the Balkans, Center for Strategic and International Studies (CSIS), Washington, D.C.

Meron, T., 1999. Crimes Under the Jurisdiction of the International Criminal Court, in: Von Hebel, H., Lammers, J.G., Schukking, J. (Eds.), Reflections on the International Criminal Court. TMC Asser Press, The Hague, pp. 47-55.

Murphy, R., 2003. United Nations Military Operations and International Humanitarian Law. Criminal Law Forum 14, 153-194.

Murphy, R., 2006. An Assessment of UN Efforts to Address Sexual Misconduct by Peacekeeping Personnel. International Peacekeeping 13, 531-546.

Oswald, B., 2007. The Law on Military Occupation: Answering the Challenges of Detention During Contemporary Peace Operations? Melbourne Journal of International Law 8, 311-326. 
Palwankar, U., 1993. Applicability of international humanitarian law to United Nations peace-keeping forces. International Review of the Red Cross, 227-240.

Plaut, M., 2008. UN troops 'armed DR Congo rebels' BBC News, http://news.bbc.co.uk/go/pr/fr/-/2/hi/programmes/panorama/7331077.stm.

Robinson, D., 2001. The Context of Crimes Against Humanity, in: Lee, R.S. (Ed.), The International Criminal Court: Elements of Crimes and Rules of Procedure and Evidence. Transnational Publishers, Inc., Ardsley, NY, pp. 61-79.

Rowe, P., 2000. Maintaining Discipline in United Nations Peace Support Operations: The Legal Quagmire for Military Contingents. Journal of Conflict and Security Law 5, 45-62.

Rowe, P., 2004. War Crimes, in: McGoldrick, D., Rowe, P., Donnelly, E. (Eds.), The Permanent International Criminal Court. Hart Publishing, Oxford and Portland Oregon, pp. 203-230.

Rowe, P., 2006. The Impact of Human Rights Law on Armed Forces. Cambridge University Press, Cambridge.

Rückert, W., Witschel, G., 2001. Genocide and Crimes Against Humanity in the Elements of Crimes, in: Fischer, H., Kress, C., Lüder, S.R. (Eds.), International and National Prosecution of Crimes Under International Law. Berlin Verlag, Berlin.

Sagala, J.K., 2006. HIV/AIDS and the Military in Sub-Saharan Africa: Impact on Military Organizational Effectiveness. Africa Today 53, 53-77.

Sassoli, M., Bouvier, A.A., 1999. How Does Law Protect in War? Cases, Documents and Teaching Materials on Contemporary Practice in International Humanitarian Law. International Committee of the Red Cross, Geneva.

Schabas, W.A., 2001. The Jelisic Case and the Mens Rea of the Crime of Genocide. Leiden Journal of International Law 14, 125-139.

Schabas, W.A., 2008. Article 6 Genocide, in: Triffterer, O. (Ed.), Commentary on the Rome Statute of the International Criminal Court, 2nd ed. C.H. Beck, Hart, Nomos, Muenchen, Oxford, Baden-Baden.

Shraga, D., 2000. UN Peacekeeping Operations: Applicability of International Humanitarian Law and Responsibility for Operations-Related Damage. American Journal of International Law 94, 406-412. 
Sivakumaran, S., 2010. War Crimes before the Special Court for Sierra Leone. Journal of International Criminal Justice 8, 1009-1034.

Tittemore, B.D., 1997. Belligerents in Blue Helmets: Applying International Humanitarian Law to United Nations Peace Operations. Stanford Journal of International Law 33, 61-117.

Triffterer, O., 2001. Genocide, Its Particular Intent to Destroy in Whole or in Part the Group as Such. Leiden Journal of International Law 14, 399-408.

Vandenberg, M., 2002. Hopes Betrayed: Trafficking of Women and Girls to PostConflict Bosnia and Herzegovina for Forced Prostitution, Human Rights Watch, New York, Vol. 14, No. 9 (D).

Vité, S., 2004. L'applicabilité du droit international de l'occupation militaire aux activités des organisations internationales. International Review of the Red Cross 86, 934.

von Hebel, H., Robinson, D., 1999. Crimes within the Jurisdiction of the Court, in: Lee, R.S. (Ed.), The International Criminal Court: The Making of the Rome Statute. Kluwer Law International, The Hague, pp. 79-126.

Werle, G., 2009. Principles of International Criminal Law, 2nd ed. T.M.C. Asser Press, The Hague.

Zimmerman, A., 2008. Preliminary Remarks on para. 2 (c)-(f) and para. 3: War crimes committed in an armed conflict not of an international character, in: Triffterer, O. (Ed.), Commentary on the Rome Statute of the International Criminal Court, 2nd ed. C.H. Beck, Hart, Nomos, Muenchen, Oxford, Baden-Baden, pp. 475-504.

Zwanenburg, M., 1999. Double Standards in Peacekeeping? Subcontracting Peacekeeping and International Humanitarian Law. Leiden Journal of International Law $12,753-757$.

Zwanenburg, M., 2005. Accountability of Peace Support Operations. Martinus Nijhoff Publishers, Leiden. 